\title{
Edith Stein's Example: Putting Empathy into Praxis
}

\author{
David Strong \\ Department of Literature \& Languages, University of Texas at Tyler \\ 3900 University Blvd., Tyler, TX \\ 903-566-7373 E-mail: dstrong@,uttyler.edu
}

\begin{abstract}
This article examines how Edith Stein's philosophical theory of empathy informs not only her scholarly discourse, but also the decision to dedicate her life to others. It first explicates the primary tenets of her theory, situating them within the context of early phenomenology as inspired by Edmund Husserl's writings. It then chronologically charts those personal events that best display her efforts to put into praxis its principles. From being a volunteer nurse aiding the wounded during World War I to comforting those being sent to the concentration camps during Hitler's regime, she continually privileges an empathetic awareness to understand those factors affecting the other's state of mind and instill a sense of dignity that betters his or her person. The interlacing of these experiences underpins her conversion from Judaism to Christianity as well as a deep-seated desire to forge a meaningful connection with others. A concerted attentiveness to another's beliefs and needs, whether they are intellectual, emotional, or spiritual, depicts the kind of affection that she exemplified on a daily basis.
\end{abstract}

Keywords: Edith Stein, Phenomenology, Empathy, Holocaust

DOI: $10.7176 / \mathrm{JPCR} / 50-05$

Publication date: September 30th 2020

\section{Edith Stein's Empathy}

The story of Edith Stein is a remarkable one. Its narrative centers upon her participation in two dominant religions-Judaism and Catholicism-as well as in a burgeoning field of philosophy that transforms the epistemological landscape, namely phenomenology. Her devotion to the thought subtending these spiritual and academic institutions reverberates to this day. As a victim of the Holocaust, she sacrificed everything for her religious heritage, thus becoming a representative of the tragedy inflicted upon her people. As a Catholic convert, she sought to exercise the virtues of compassion and charity, promoting human dignity in the most forsaken places. And, as a philosopher, she wrote a seminal text on the operation and purpose of empathy. ${ }^{1}$ The interlacing of these experiences underscores a deep-seated desire to forge a valued connection with others. Faith conjoined with phenomenological tenets leads her to reject the idea that human behavior and its expressions simply possess the potential to reveal something significant about that person, relying upon the intellect to ascribe it meaning. Rather, her convictions prompt her to exercise a concerted attentiveness discloses another's motivations, beliefs, and needs. Whether intellectual, emotional, or spiritual, her affection epitomizes the kind of care that can be put into praxis and ultimately transcends mundane concerns.

While many biographies chart the seemingly eclectic details of her life and many scholarly articles examine the profundity of her philosophical acumen, I would like to bridge these two related but distinct facets of her life to show that her tenets of empathy find fruition most fully in real-life experiences. ${ }^{2}$ Her academic writings coupled

\section{Notes}

Note 1 Stein was the second woman in German history to receive a doctorate in

philosophy. See Antonio Calcagno, “Assistant and/or Collaborator? Edith

Stein's Relationship to Edmund Husserl's Ideen II" in Contemplating Edith

Stein: A Collection of Essays, ed. Joyce Avrech Berkman (Notre Dame, IN:

University of Notre Dame Press, 2006), 263.

Note 2 Waltraud, Herbstrith, Edith Stein: A Biography. trans. Bernard Bonowitz (San

Francisco: Ignatius Press, 1985); Elisa Magrì and Dermot Moran, Empathy,

Sociality, and Personhood: Essays on Edith Stein's Phenomenological 
with a deep religiousness refine her belief in the value of others, and the decision to champion this principle transforms her thought from an abstract to a pragmatic endeavor which betters both her person and those who come into contact with her. Expounding upon her view, Alastair MacIntrye writes: "Empathetic awareness allows us to understand others in the same way. . . . And just as in the case of certain others we find ourselves, after we have become aware through iterated empathy of how they view us." ${ }^{1}$ Making the effort to align our thoughts and feelings with another generates a positive rapport that allows us to realize our potential as human beings.

Before discussing how Stein makes this realization active in her daily life, I would first like to explicate the primary tenets of her philosophy. Essentially, empathy increases the means to apprehend the extent of our possibilities. It engenders self-knowledge. Seeing ourselves as an "object" from the other's perception reveals a facet of our person that, without this experience, would remain beyond our grasp. ${ }^{2}$ This insight "is foreign to the natural standpoint, and it is empathy that occasions it." ${ }^{3}$ We learn how to exercise more capably not only those talents and skills that we already rely upon, but also those that, up to that point, have remained hidden from our view. Its reflexivity produces an attentiveness of how to utilize different avenues of knowing. Consider watching another person push aside his fear for self-preservation and run into a burning building to rescue a child crying out in fear. This event would cause the observer to look inside and determine if he could perform a similar heroic act. Adopting another's perspective thus encourages us to discover and ponder those possibilities that we have yet to consider. It is, as Sarah Borden writes, where "I become real to myself."

An empathetic embrace reveals a horizon of unfolding of meaning that enlightens the observer of another's state of mind and makes him an active participant in the experience. By assessing and even reciprocating an affect similar to another's emotional expression, the individual can determine more accurately what comprises the other's motivations and intentions. This continually expanding perception allows one to become more fully aware of what he or she values above all else. ${ }^{5}$ She claims in her later writings that this is a distinct human power that enables one to fashion a harmonious connection with others.

But human souls are capable, by virtue of their free spirituality, of opening themselves in loving self-giving to one another and of receiving one another into their own selves - never, to be sure, as completely as is the case with a soul that abide in God, but in some greater or smaller measure. And this receiving is not merely a knowing comprehension which leaves the object [Gegenstand] standing by itself at a distance and is thus of small significance for the soul, but an inward reception of the object, a reception which aids in nourishing and forming the soul. ${ }^{6}$

Investigations (New York: Springer Publishing, 2017).

Note 3 Alastair MacIntyre, Edith Stein: A Philosophical Prologue 1913-1922 (Lanham,

MD: Rowman \& Littlefield, 2006), 86.

Note 4 Edith Stein, On the Problem of Empathy, trans. Waltraut Stein (Washington,

D.C.: ICS Publications, 1989), 88.

Note 5 Stein, Problem of Empathy, 89.

Note 6 Sarah Borden, Edith Stein (London: Continuum, 2003), 29.

Note 7 For a discussion of Stein's view that empathetic acts engender self-knowledge, see Sarah Borden Sharkey, Thine Own Self: Individuality in Edith Stein's Later

Writings (Washington, DC: Catholic University of America Press, 2010), 121.

Note 8 Edith Stein, Finite and Eternal Being, trans. Kurt F. Reinhardt (Washington,

D.C.: ICS Publications, 2002), 514. 
The very design of our creation empowers us to enter into another's mind, use this knowledge selflessly, and express a genuine affection for that person. Although the understanding conveyed and reciprocated may not be as complete as when acquired in God's presence, empathy provides a penetrating insight into what is actual and what is possible. Its limitations underscore the asymmetry between them, thus ensuring that one does not lose his sense of self within the other. Stein also claims that grace is necessary for self-understanding, for it takes the bandages off our eyes and "initiates the future fulfillment of the original ordination of the natural being of people." "The effort to apprehend the epistemic value of this interpersonal exchange simultaneously reveals a heightened ability to know others and a dependence upon God. Empathy, therefore, is not some casual or passive response to another's actions or emotional reactions. Rather, it demands a keen awareness of what that moment says about oneself in relation to that person.

With this in mind, explicating its operation takes on an added significance. It is not some theoretical exercise designed to advance academic scholarship, but enables one to realize how to utilize most effectively the influx of information conveyed by that experience. Superseding inference and speculation, direct, unmediated experience possesses an insight that transcends the quotidian concerns facially expressed by another's behavior. Whether through facial or bodily movements, it elevates one's consciousness to grasp the import of these actions, for they hold an intrinsic psychological significance. Using the example of a blush, Stein claims that it does not signify an emotion like shame or embarrassment, but actually contains significance in itself. For her, "meaning and symbol have something in common which forces them both to be called 'expression' repeatedly. Together they constitute the unity of an object." 2 Recognizing this relation and utilizing our past knowledge of what constitutes this behavior makes the blushing intelligible. ${ }^{3}$ The confluence of the cognitive and affective in explaining this moment establishes the other as the center of reference. As a result, Stein claims that "An action is a unity of intelligibility or of meaning because of its component experiences have an experienceable connection." 4

By having to assess the experience's intelligibility, the observer recognizes this as a genuinely original phenomenon. It exists solely between them, distinguishing the disparity of their roles. Properly aligning one's thoughts and feelings involves far more than an impulsive reaction. It is a conscious mode of knowing that reveals how the two perspectives differ intrinsically. That the experiences are qualitatively different attests to the fact that each one is a minded individual who can respond freely to the other's actions. Even though empathy affirms the reality of the other's experience and the psychological inimitability underlying the behavior, it cannot penetrate fully his psychic life. It is in principle inaccessible to direct perception. ${ }^{5}$ A sharp delineation, therefore, exists between the act of experiencing and the content experienced. Empathy is, as Marianne Sawicki explains, "an act

Note 9 Stein, Finite and Eternal Being, 526-7.

Note 10 Stein, Problem of Empathy, 81.

Note 11 Eugene Cassirer's line of reasoning follows the same vein when he writes, \Instead of

asking by what processes of logical inference or of aesthetic

projection the physical becomes psychical, it must follow perception back to

the point where it is not a perception of things but purely a perception of

expression, and where, accordingly, it is inside and outside in one" (Cassirer,

The Philosophy of Symbolic Forms III [New Haven: Yale University Press,

1957], 84)

Note 12 Stein, Problem of Empathy, 84.

Note 13 For a similar line of argumentation, see Edmund Husserl, Analysen zur passive

Synthesis: Aus Vorlesungs und Forschungsmanuskripten, 1918-1926, ed. M.

Fleischer, Husserliana 11 (The Hague: Martinus Nijhoff, 1966), 240. 
distinguished by its content." It forms "an exemplary basis for the consideration of the essence" of that moment and what it reveals about the other's distinctiveness. ${ }^{2}$ The essential differences thus illuminate the ineffable quality of the self.

This limitation preserves the self-other distinction. Without this element of the unknown, the experience would no longer belong to the observer. He would lose himself by merging with the other which would inevitably slip, as compeer Jean-Paul Sartre warns, into an unwieldy solipsism. ${ }^{3}$ Rather, individuality establishes the original presence of the other as "the one who looks at me."4 Stein's mentor, Edmund Husserl, believes that this delineation allows us to attain a higher level of understanding where we become conscious of something greater than ourselves. We come face-to-face with an otherness of a completely new kind. ${ }^{5}$ In effect, it is a dialogue where another's actions prompt one to assess not only that person's state of mind, but also consider his role in this experience. Reality thus incorporates a multiplicity of perspectives that forge a connection between the two people. For Stein, empathy "is a kind of act of perceiving. . . . [It] is the experience of foreign consciousness in general." " No matter how limited, this awareness determines the structure and quality of our responses in grasping the other's psychic life. $^{7}$

The decision to participate in this endeavor stems from an inner desire to cultivate a deep interpersonal knowledge and gain a fulfilling experience. This interplay contains its own type of originality which separates it from other means of knowing and feeling. Stein famously points out that empathy is a unique expression different from conventional emotions, such as joy or sorrow. Being in a class by itself, a sui generis, it is not felt as one's own

Note 14 Marianne Sawicki, Body, Text, and Science (New York: Springer Publishing,

1997), 97.

Note 15 Stein, Problem of Empathy, 4. In Philosophy of Psychology and the

Humanities, Stein how "our glance rests in the natural attitude with everything

that's in it, is a correlate of our consciousness. . . .To every object and to every

class of objects there correspond certain adapted coherences of

consciousness." She discusses in detail how the intensity of these experiences

produces a stronger experience than the content seems to warrant. See Stein,

Philosophy of Psychology and the Humanities, trans. Mary Catherine

Baseheart and Marianne Sawicki [Washington D.C.: ICS Publications, 2000],

7).

Note 16 Jean-Paul Sartre, Being and Nothingness: An Essay in Phenomenological

Ontology, trans. H. E. Barnes (London: Routledge, 2003), 293-4.

Note 17 Sartre, Being and Nothingness, 293.

Note 18 Edmund Husserl, Zur Phänomenologie der Intersubjektivität: Texte aus dem

Nachlass, vol. iii, 1921-1928, ed. Iso Kern, Husserliana 14 (The Hague:

Martinus Nijhoff, 1973), 442.

Note 19 Stein, Problem of Empathy, 11.

Note 20 Stein, Problem of Empathy, 11. 
feeling or recollected as a past experience, but exists in the here and now, given by the other. ${ }^{1}$ Even if initiated by an affective reaction, the response incorporates the intellect's divers powers, such as memory and imagination. These powers enable us to carry out the experience that was already co-given to us and allows us to effect an act that can support or accentuate the joy existent in that moment. ${ }^{2}$ It presents an opportunity to construct a fulfilling rapport founded upon the value of both persons.

While discussing what constitutes a relational construct that gives purpose to existence is the lifeblood of philosophers, their ideas often remain just that - theories and postulates. Stein, however, puts into praxis her notion of empathy on a scale that is rarely encountered. The precision of her interpersonal understanding allows her to express a profound care for those in need and, in the process, betters her own person. While an academic career for a woman during this time would never treat her as an equal, she bolstered her dignity by dedicating herself to a life of charity. ${ }^{3}$ Her altruistic drive manifests itself in her vocational choices. During World War I, she volunteered as a nurse for the Red Cross. And, after finding inspiration in the autobiography of St. Teresa of Avila years later, she joined the convent and became a nun in the Carmelite Order. Whether facing the discrimination of higher education hiring practices or scratching out a living as a tutor and traveling scholar, she never forsakes her belief in the inherent dignity of people. As illustrated most strikingly when comforting those sent to Auschwitz, she exercises empathy in a truly unparalleled way.

Convinced that a greater good involves working with others, Stein is swept up by patriotic zeal, postpones her doctoral studies, and works as a nurse at an army hospital. Whether giving aid to soldiers recovering from war wounds or disease, she gave herself wholeheartedly to the endeavor, shying away from nothing. She writes, "I got the impression that the sick were not used to getting loving attention and that volunteer helpers therefore could find endless opportunities to show their own compassion and love of neighbor in these places of suffering." ${ }^{4}$ In accord with her future philosophical views, she looked at the soldiers as not just bodies consisting of different

Note 21 She writes, "Thus empathy is a kind of act of perceiving sui generis. [It] is the

experience of foreign consciousness in general, irrespective of the kind of

experiencing subject or of the subject whose consciousness is experienced"

(Problem of Empathy, 11).

Note 22 Stein, Problem of Empathy, 93.

Note 23 Although the discrimination that she faced as a woman in academe lies outside

the scope of this article, she addresses this problem in her lecture, "Problems

of Women's Education” delivered in Münster in 1932 at the German Institute

for Scientific Pedagogy. See Die Frau: Ihre Aufgabe nach Natur und Gnade in

Werke, vol. 5, ed. L. Gelber (Freiburg im B.: Herder, 1959), trans. Freda Mary

Oben as Woman (Washington: Institute of Carmelite Studies, 1987). For a

critical assessment of Stein's discussion of the inherent relation between

women and empathy, see Antonio Calcagno, The Philosophy of Edith Stein

(Pittsburgh: Duquesne University Press, 2007), 63-80.

Note 24 Edith Stein, Life in a Jewish Family: Her Unfinished Autobiographical

Account, trans. Josephine Koeppel (Washington, D.C.: ICS Publications,

1989), 298. 
parts and aspects, but at their entire person, deserving of both emotional and intellectual support. Appreciating their mindedness supplements the basic human need to feel connected with others. She performs her duties with a selflessness that prioritizes their relationship so that she does not let her response disintegrate into a maudlin sentiment. Her attentiveness respects the distance between their condition and her role. As a result, she was "equally popular with the wounded soldiers, her colleagues, and her superiors," which ultimately contributed to her receiving the medal of valor. ${ }^{1}$

Following the war, she returned to her studies and completed her Ph.D. in 1916. Despite graduating with the highest honors, she could not find gainful employment. Although no laws explicitly restricted woman from being hired as full-time professors, the practice in academe was to hire only men. The letter of recommendation written by her dissertation director, Edmund Husserl, underlines the gender barrier: "Should the academic career be opened to women, I could recommend her highly and warmly for approval as a university professor." 2 In fact, a woman would not hold a lecturer post in Philosophy at a German university until the 1950s. In order to keep abreast of the scholarly developments in the field, she took a position as an assistant for Husserl. In time though, this job failed to satisfy her yearnings to submit her own research for publication and teach. ${ }^{3}$

Over the next few years, she kept active by giving private instruction, writing, and lecturing part-time. While staying with friends in the spring of 1921, she came across the The Autobiography of St. Teresa of Avila. She was so taken with the mystic's wisdom that she read it in one night, proclaiming "This is the truth." 4 Though raised in a Jewish household, she had slipped into atheism during her university years (which is not an uncommon experience for graduate students), but these words spoke to her with such force that she elected not only to convert to Catholicism, but also join the same order as her spiritual exemplar. This radical decision sometimes overshadows her reputation as a philosopher, but this article strives to show that her religious expression is in many ways an extension of her higher education. ${ }^{5}$ Her scholarship in phenomenology impressed upon her the necessity of cultivating relationships and recognizing the interpersonal value of these lived experiences. In effect, it affirms her belief in humanity's goodness and, as such, conforms to Teresa's writings: "And be certain that the

Note 25 Stein, Life, 16; for a discussion about the awarding of the medal, see Waltraud

Herbstrith, Edith Stein: A Biography (San Francisco: Ignatius Press, 1985), 53.

Note 26 Edith Stein, Edith Stein: Letters to Roman Ingarden, trans. Hugh C. Hunt

(Washington, D.C.: ICS Publications, 2014), 63. A copy of the actual letter is

also found on this page.

Note 27 She writes in a letter, "Putting manuscripts in order, which was all my work

consisted of for months, was gradually getting to be unbearable for me, nor

does it seem to me to be so necessary that, for its sake, I should have to

renounce doing anything on my own" (Stein, Self-Portrait in Letters: 1916-

1942, trans. Josephine Koeppel [Washington, D.C.: ICS Publications, 1993],

23).

Note 28 Josephine Koeppel, Edith Stein: Philosopher and Mystic (Collegeville, MN:

The Liturgical Press, 1990).

Note 29 Calcagno notes that the majority of scholars who study Stein direct their

attention to her biographical and religious writings. See Antonio Calcagno,

“Assistant and/or Collaborator?” 263. 
more advanced you see you are in love for your neighbor the more advanced you will be in the love of God, for the love His Majesty has for us is so great that to repay us for our love of neighbor He will in a thousand ways increase the love we have for Him." When properly executed, an attentiveness to another's condition displays a genuine affection that underscores our need for one another. It complements the Christian principle that love for our neighbor belongs to necessary ethics, for it is necessarily related to our love for God. In other words, a fundamental love for God means that we cannot but love our neighbor as well.

For Stein, cultivating an interior life opened up an entirely new world to her. In a letter to colleague, she describes this awakening, "All prior realities become transparent; the genuine sustaining and motivating strengths become perceptible. Previous conflicts become trivial!"' This realization fortifies her conviction to put into praxis her learning in a personal, practical way. While excluded from the stations of academe, she found inclusion in a faith that encouraged her to utilize her philosophical learning to grasp the thought process of another and use this knowledge to deepen their rapport. While her empathetic link first centered upon God, it expanded outwards to include those open to her compassion. Taking the necessary steps to align one's will with the divine produces a deep-seated affection for all of creation and, in turn, loving one's neighbor inculcates a devout conviction in our inherent goodness. Stein's scholarly works may have explicated empathy's operation, but it did not assert the need to engender a positive flow. For example, an observer could apprehend the other's mental states via their interaction, and choose to use this knowledge for selfish purposes, such as ascertaining the other's motivations solely to manipulate him for personal gain. With this epiphany, Stein now makes every effort in her daily life to make certain that her empathy generates not only a keen insight into that person's well-being, but also an authentic commitment to their innate worth. Fellow Carmelite Sister Maria Amata Neyer remarks, "It was 'the truth of things,' the 'things themselves,' the objects. Now in Teresa of Avila she was filled with the truth of love that is not knowledge, but relationship." 3 Being attuned to this saint's wisdom helps her realize that a valued life does not stem from patiently heeding custom's dictates or the prevailing prejudices of her time, but from recognizing her own value. By directing her energies to apprehend the divine's state of being - no matter how limited this endeavor may be-she strengthens her faith and, in turn, enriches her very self. She sees first-hand that God neither discriminates nor denigrates. As a result, she concludes, "I found the place where there is rest and peace for all restless hearts." 4

Here, she sharpens her focus by structuring her thoughts and feelings to correspond with the divine's will. This connection, however, must draw a bold line of demarcation between what He offers and what she can do. While His knowledge "is not mistaken about people's experiences. ., [her] experiences do not become God's own, either." A self-other distinction validates the uniqueness of each one's perception. Some people may facially believe that losing themselves within the divine increases spiritual awareness, but they run the risk of ignoring the fact that His essence is pure and their person is not. In Christian thought, we must be conscious of our dependence upon His grace. Not everyone is bound to conform to the divine will in willing those things because not everyone is obliged to know everything willed by the divine will. Moreover, we are not obliged to fulfill the affirmative divine precepts. This choice rests upon our resolve to pursue this end. It requires a diligence in mirroring the infinitude of His love to fashion a steadfast bond. It is not for the weak-minded or self-centered. Teresa recollects

Note 30 Teresa of Avila, Interior Castle, Bk.5.3.8, trans. Kieran Kavanaugh and Otilio

Rodriguez (Mahwah, NJ: Paulist Press, 1979), 100.

Note 31 Stein, Letters to Roman Ingarden, 259. This letter is written on November 8,

1927.

Note 32 Maria Amata Neyer, Edith Stein: Her Life in Photos and Documents

(Washington, D.C.: ICS Publications, 1999), 34.

Note 33 Stein, Self-Portrait in Letters, 47.

Note 34 Stein, Problem of Empathy, 11. 
the labor-intensive nature of conforming herself to His will, "I threw myself on the ground beside it, my tears flowing plenteously, and implored Him to strengthen me once for all, so that I might never offend Him anymore."

Through contemplation, God is given to her as an object that bears psychological states. ${ }^{2}$ A cognizance of what He offers, therefore, supplants the use of facial expressions and bodily gestures as the primary phenomena to consider when structuring an empathetic encounter. One particular advantage of structuring one's life upon His will is the continuous opportunities to experience true goodness. The resultant bond transcends a simple affective response. It allows her to see the divine as a wholly distinct being, for He is not susceptible to those intellectual constraints limiting a human purview. Subsequently, she refines her ability to express herself in a way that fosters charity and selflessness. The core of their connection thus stems from the radical otherness of God, and accounts for why Stein states that "it is not something about which I can 'report' in a letter." ${ }^{3}$ Reality becomes founded upon the divine's presence. By directly apprehending His immediacy, she does not have to infer His existence. She knows Him intimately. His transcendence, however, preserves their asymmetry. As Emmanuel Lévinas writes, "If one could possess, grasp, and know the other, it would not be other." Embracing the goodness that flows through Him constructs a substantive relationship that supersedes those limitations affecting the depth of our understanding. Overcoming these obstacles produces a dynamic intersubjectivity that distinguishes Stein's sense of self and emboldens her willingness to adopt another's perspective. ${ }^{5}$

The disparate experiences between working for Husserl and reading Teresa of Avila's revelations bring to light markedly different perceptions of assessing her value. In the case of the former, she is a person whose scholarly worth remains underappreciated because of her gender. For the latter, she is a dedicated novitiate whose conviction in a higher truth promises greatness. In order to realize this potential, she conjoins her intellectual achievements with faith-inspired beliefs to master a keen awareness of the divine. The first step rests upon situating herself in a position that gives her the most direct means to put into practice her beliefs. Upon converting to and receiving the sacraments in the Catholic faith, she takes up a teaching position at a school run by the Dominican sisters in Speyer, Germany. Here, she follows the path outlined by Teresa. Living in a room adjacent to the nuns, she joined them in daily mass and structured prayer. She writes that "living behind the sheltering walls of a convent, at heart-and this I may surely say without any presumption - like a real nun, even though I wear no veil and am not bound by vows or enclosure." ${ }^{6}$ Despite the clarity of Teresa's example, she does not presume that becoming a nun necessarily results in a virtuous empathy. Conscious of the inherent challenges of accessing the divine, she postpones her vows so that she can discern her readiness. This act alone demonstrates a heightened appreciation for the selfless commitment in focusing her attention upon God.

While her response to Teresa may spark the epiphany, the force of her choice to emulate Teresa's thoughts and actions stem from will. In Philosophy of Psychology and the Humanities, Stein discusses how the will presupposes a certain aliveness as well as an objective basis including direction-giving motives. Through these two inclinations, it generates its power from itself and spontaneously draws from "the lifesphere." 7 She accords the will a freedom distinct from the intellect's dictates. It "harbors an impulse as a core within itself" and draws from this "lifepower"

Note 35 Teresa of Avila, The Autobiography of St. Teresa of Avila, trans. David Lewis

(Rockford, IL: Tan, 1997), 65.

Note 36 Stein, Problem of Empathy, 5-6.

Note 37 Stein, Self-Portrait in Letters, 47.

Note 38 Emmanuel Lévinas, Time and the Other, trans. R. A. Cohen (Pittsburgh:

Duquesne University Press, 1987), 90.

Note 39 Edmund Husserl stress that one's personhood is intersubjectively constituted.

See Husserl, Zur Phänomenologie der Intersubjektivität, 14:175.

Note 40 Stein, Self-Portrait in Letters, 47.

Note 41 Stein, Philosophy of Psychology, 87-90. 
to initiate action. ${ }^{1}$ Moreover, she does not assign it a teleological orientation. The will does not have to pursue an end perceived as an unqualified good. If it were to necessarily seek happiness, then it would necessarily force the intellect to continually consider happiness, which is false. An ethically sound act thus depends upon the free will targeting an object which right reason judges to be meritorious. This view, however, does not mean that an empathetic act must be virtuous. One can choose to conform oneself with a person who does not act morally sound. Of course, in the context of drawing closer to God, the will directs us towards recognizing that the life of grace flows into us because by our very nature we are related to the divine. We are capable of receiving into ourselves His divine life, for "this linkage between head and members has a threefold foundation. It rests upon nature, freedom, and grace." Consequently, choosing to coordinate our perception with the divine's font of goodness fulfills the essence of our nature. It is a process that perfects our humanness.

After ten years of working and praying alongside the nuns, Stein elects to enter into the same order as her exemplar. She becomes a Carmelite novice in 1934 and takes her first vows a year later. While she continued writing, which included a family history and a philosophical work that examined Catholic tradition through the lens of phenomenology, she learned how to become more attuned to the subtle expressions of divine care found in this world. ${ }^{3}$ By caring out her duties faithfully, she comes to realize how the interactions with her fellow sisters brought "a source of deep peace and hearty joyousness and a fountain of grace that bubbles over everything." 4 Mirroring the same kinds of joys emanating from the divine confirms a mutual intimacy because she can now share them with the beloved. It allows her to ascribe and reflect on the real intentions of what constitutes the divine.

While some may believe that empathizing with God is a futile endeavor since He is perfect and we are not, but such a view ignores the elemental connection between God and creation. The kind of empiricism that is possible may not satisfy a skeptical observer, but the sense of wholeness engendered by being attuned to His goodness enhances one's humanness. We are conscious living beings. That we can align our minds with the divine will and participate in these experiences provides certitude about His goodness. Stein refers to this awareness as "the zero point of orientation." "From here, one becomes aware of one's own body in relation to the other, which engenders a new, higher order of empathy that one can perform. As Kris McDaniel explains, it is "through the higher-order empathetic act that I come to recognize myself as a physical object imbued with psychological states. Not only must I have empathy but there must also be other people who have empathy in order for me to have this kind of self-knowledge." Therefore, an informed connection with God shows that each person possesses the means to cultivate a mutual intimacy. A true knowing enables us to embrace another's perspective and better our selfunderstanding.

Note 42 Stein, Philosophy of Psychology, 87

Note 43 Stein, Finite and Eternal Being, 523

Note 44 The former is entitled, Life in a Jewish Family: Her Unfinished

Autobiographical Account, ed. L. Gelber and Romaeus Leuven, trans.

Josephine Koeppel (Washington, D.C.: ICS Publications, 1986); the latter is

Potency and Act, trans. Walter Redmond (Washington, D.C: ICS Publications,

2009).

Note 45 Edith Stein, The Hidden Life, trans. Waltraut Stein (Washington D.C.: ICS

Publications, 1992), 6.

Note 46 Stein, Problem of Empathy, 43.

Note 47 Kris McDaniel, "Edith Stein: On the Problem of Empathy," in Ten Neglected

Philosophical Classics, ed. Eric Schliessen (Oxford: Oxford University Press,

2017), 218. 
No matter how strong or informed this embrace can become, Stein consistently stresses the delineation between the parties: "two subjects are separate and not joined together . . . by a consciousness of sameness or a continuity of experience."1 For her and Husserl, empathy is an act of perceiving; it is the experience of foreign consciousness. No matter how much the observer ascertains, he can never fully appreciate the originality of the other's experience. If that occurred, then his being would be subsumed by the other, forsaking its uniqueness. Rather, he acknowledges it as an experience lived through by another. The experiences that Stein seeks are those that empower her to grasp His will more accurately and assuredly. And, the manner in which she achieves this goal is by extending a similar attentiveness and affection for those whose faith is attacked and dignity denigrated.

On the surface, leading the life of a cloistered nun seems counterintuitive to her actively engage others and immerse herself in this experience. As opposed to the Franciscans or Dominicans who lead itinerant lives, preaching and teaching, the Carmelites separate themselves from the world around them dedicating themselves to a life of prayer. If she believed so strongly in advancing her awareness of the divine via assisting others, then she could have joined an order that actively seeks to aid the less fortunate. Yet, such a view misunderstands the expression of empathy. Interactions may become more limited, but this does not diminish the care invested in appreciating her fellow sisters' well-being. In Freda Oben's biography which records the accounts of the nuns who lived with her, she relates, "I have heard that Edith had a special gift for relating to people. She intuitively felt the state of mind of others and knew what they needed and how to encourage them. Her love and goodness were natural." 2 The conviction in another's virtue sharpened her focus and inspired her actions. Ultimately, location does not determine the efficacy of extending oneself to others as much as a yearning to strike a harmonious connection.

This realization drives Stein forward as she makes her final vows four years later on April 21, 1938. Adopting the name, Sister Teresa Benedicta of the Cross, she takes her place in the Cologne monastery. Here she aspires to achieve a wholeness that betters her very being and, in turn, those who come in contact with her. The goodness drawn from this connection does not depend upon constant reassurance, for such a need lies in the realm of the sublunary lover, but stems from a higher, more transcendent understanding of what defines the self. She writes, "The formation of an unshakable bond with all whom life brings in my way, a bond in no way dependent on dayto-day contact, is a significant element in my life." 3 The standard of measurement revolves around grasping another's needs and spiritual desires rather than prevailing notions of what defines success. Its strength derives from the honesty exchanged between them. The resultant trust and shared understanding empowers her to empty herself of any material or worldly concerns, allowing her to become open to the other's situation.

Despite the honesty underpinning the fulfillment she seeks, it has no bearing upon the political movements shaping German society. In January of 1931, Adolph Hitler assumed power as chancellor of Germany and two months later, the first concentration camp opened in Dachau. Fearing that the growing anti-Semitism would endanger the convent, she transferred to the Echt convent in Holland. Yet, when the Dutch bishops of occupied Holland wrote a letter condemning the pogroms and deportation of Jews (July 26, 1942), Hitler retaliated by ordering the arrest of all non-Aryan Roman Catholics. Stein was seized by the Gestapo on August 2. She and her sister Rosa, who had also converted and was serving at the Echt Convent, joined many other Jewish Christians as they were taken to a transit camp in Amersfoort and then to Westerbork.

A young detainee, Etty Hillesum, who was at the camp when Edith and her sister arrived, left behind a journal describing Westerbork's appearance when getting off the train: "Suddenly there was a village of wooden barracks, set between the heath and sky, with a glaringly yellow lupin field in the middle and barbed wire all around. And there were human lives as well, thick as flies. . . . There is mud, so much mud that somewhere between your ribs you need to have a great deal of inner sunshine if you don't want to become the psychological victim of it all."'4

Note 48 Stein, Problem of Empathy, 10-11.

Note 49 Freda Mary Oben, Edith Stein: Scholar, Feminist, Saint (Staten Island: Alba

House, 1988), 29.

Note 50 Stein, Self-Portrait in Letters, 46.

Note 51 Etty Hillesum, An Interrupted Life: The Diaries, 1941-1943 and Letters from

Westerbork, (New York: Henry Holt, 1996), 242. 
Its grim desolation would certainly undo one's surety of self, undermining the belief in humanity's goodness. Yet, Stein held fast to her conviction that the relation between the individual and other are inviolate. Understanding that her connection with God extolled the dignity of being human, she saw her purpose in empathizing with those in need. This action supplemented her own relation with the divine, allowing her to realize her potential. "Helping Christ carry his cross fills one with a strong and pure joy, and those who may and can do so, the builders of God's kingdom, are the most authentic children of God." 1 Yet, being empathetic involves more than simply being sensitive to another's plight. One must be willing to withstand whatever outside pressures seek to upset the bond between people. She privileges this bond above all else, for through this interpersonal knowing, she becomes more fully aware of the divine offers and what she values. ${ }^{2}$ It epitomizes the type of person whom she has chosen to be. The depth of her understanding comes to light when she comforts the women and children in the camp. Julius Marcan, a survivor who was there at the same time, marks how Stein resisted the dehumanizing effects of this environ and how she stayed true to her heart:

It was Edith Stein's complete calm and self-possession that marked her out from the rest of the prisoners. There was a spirit of indescribable misery in the camp; the new prisoners, especially, suffered from extreme anxiety. Edith Stein went among the women like an angel, comforting, helping and consoling them. Many of the mothers were on the brink of insanity and had sat moaning for days, without giving any thought to their children. Edith Stein immediately set about taking care of these little ones. She washed them, combed their hair and tried to make sure they were fed and cared for. ${ }^{3}$

Unlike her time in World War I, she had no medications to dispense or blankets to comfort them. She had only herself to give. But, like her service as a Red Cross nurse, her attentiveness instilled in others a firm conviction in their personal worth. She never lost her sense of self or desire to enrich this connection. She gave all that she could to help them understand that goodness did exist, that a belief in others was not a misplaced ideal or illusion. Her concern transcended their immediate surroundings. Establishing a substantive connection-regardless of how brief it may be-exercises not only a mental acuity, but also displays the volition to express such a conscientious care. The Dutch official Wielek who also spent time with her in Westerbork noted her composure and the care emanating from her actions: "For a couple of days she lived in that hellhole, walking, talking and praying...like a saint. And she really was one. That is the only fitting way to describe this middle-aged woman who struck everyone as so young, who was so whole and honest and genuine."4

Within a few days, she and Rosa were placed on a train to Auschwitz, but they never entered its barracks because they were immediately deemed incapable for work and sent directly to the gas chambers. Though powerless to change its outcome, she chose to not let the circumstances undermine her capacity to grasp another's thoughts and feelings and use this knowledge to express a much-desired respect for their person. While her academic treatises present a blueprint of how to align her person with another's, her choices champion the imperative to put into praxis this knowledge. She embodies empathy's fundamental tenets. Whether referring to her as an exemplar of spiritual understanding or earnest scholar, her actions show that being attentive to others betters the world around them.

Being a part of these situations and sensations reveals a spectrum of interpersonal understanding that affirms the value of being human and the power of the body to convey this knowledge. She is not confined to a solipsistic

Note 52 Stein, Hidden Life, 93.

Note 53 MacIntyre explains that when we come to know someone well, then our

empathetic awareness of that person's particular acts enables us to ascribe

character traits to him. We can use this knowledge not only to interpret later

acts, but also grasp how they view us, adducing our own self-understanding

(Edith Stein: A Philosophical Prologue, 84-6).

Note 54 Herbstrith, Edith Stein: A Biography, 105.

Note 55 Herbstrith, Edith Stein: A Biography, 107. 
view of the world, but sees in others a truth that revolutionizes the value of experience. It apotheosizes the self in all its glory and limitations. A consciousness of others and embracing the harsh conditions that they live in provide a chance to hone her intrinsic goodness. She shuns the attitude that she should detach herself from this reality and instead inserts herself within this interpersonal dynamic. Regardless of how abhorrent or dangerous the world becomes, she gives this reality her rapt attention. The desire to perfect this kind of knowledge drives her onward to become more than a philosophic onlooker upon an objective reality. Canonized by Pope John Paul II on October 11, 1998, Stein's difficulties may occur at a time and place far different from the one we live in, but her actions convey how best to put into praxis those truths underpinning our humanness and become a paragon for others.

\section{Future Research}

Stein's example establishes the applicability of phenomenology to actual situations and people. For future research, her concept of empathy should not be seen only as a means to access another's perspective, but also to understand others as persons who possess an innate worth. In this respect, her example can serve as a crucial means to understand communal experiences. Exploring empathy's connection to values and sociality will further establish the imperative to put it into praxis.

\section{References}

Borden, Sarah, (2003). Edith Stein. London: Continuum.

Calcagno, Antonio, (2006). Assistant and/or Collaborator? Edith Stein's Relationship to Edmund Husserl's Ideen II. In Contemplating Edith Stein: A Collection of Essays. eds. Joyce Avrech Berkman. Notre Dame, IN: University of Notre Dame Press, 243-270. Calcagno, Antonio, (2007). The Philosophy of Edith Stein. Pittsburgh: Duquesne University Press.

Cassirer, Eugene, (1957). The Philosophy of Symbolic Forms III. New Haven: Yale University Press.

Herbstrith, Waltraud, (1985). Edith Stein: A Biography. trans. Bernard Bonowitz. San Francisco: Ignatius Press.

Hillesum, Etty, (1996). An Interrupted Life: The Diaries, 1941-1943 and Letters from Westerbork. New York: Henry Holt.

Husserl, Edmund, (1966). Analysen zur passive Synthesis: Aus Vorlesungs und Forschungsmanuskripten, 19181926. ed. M. Fleischer. The Hague: Martinus Nijhoff. Husserl, Edmund, (1973). Zur Phänomenologie der Intersubjektivität: Texte aus dem Nachlass, vol. iii, 1921-1928. ed. Iso Kern, Husserliana. The Hague: Martinus Nijhoff.

Koeppel, Josephine, (1990). Edith Stein: Philosopher and Mystic. Collegeville, MN: The Liturgical Press.

Lévinas, Emmanuel, (1987). Time and the Other. trans. R. A. Cohen. Pittsburgh: Duquesne University Press.

MacIntyre, Alastair, (2006). Edith Stein: A Philosophical Prologue 1913-1922. Lanham, MD: Rowman \& Littlefield.

Magrì, Elisa \& Moran, Dermot, (2017). Empathy, Sociality, and Personhood: Essays on Edith Stein's Phenomenological Investigations. New York: Springer Publishing.

McDaniel, Kris, (2017). "Edith Stein: On the Problem of Empathy." In Ten Neglected Philosophical Classics. ed. Eric Schliessen. Oxford: Oxford University Press, 195-221.

Neyer, Maria Amata, (1999). Edith Stein: Her Life in Photos and Documents. Washington, D.C.: ICS Publications. Oben, Freda Mary, (1988). Edith Stein: Scholar, Feminist, Saint. Staten Island: Alba House.

Sartre, Jean-Paul, (2003). Being and Nothingness: An Essay in Phenomenological Ontology. trans. H. E. Barnes. London: Routledge.

Sawicki, Marianne, (1997). Body, Text, and Science. New York: Springer Publishing.

Sharkey, Sarah, (2010). Thine Own Self: Individuality in Edith Stein's Later Writings. Washington, DC: Catholic University of America Press.

Stein, Edith, (1986). Life in a Jewish Family: Her Unfinished Autobiographical Account. trans. Josephine Koeppel. Washington, D.C.: ICS Publications.

Stein, Edith, (1987). Woman. trans. Freda Mary Oben. Washington: Institute of Carmelite Studies.

Stein, Edith, (1989). On the Problem of Empathy. trans. Waltraut Stein. Washington, D.C.: ICS Publications.

Stein, Edith, (1989). Life in a Jewish Family: Her Unfinished Autobiographical Account. trans. Josephine Koeppel. Washington, D.C.: ICS Publications.

Stein, Edith, (1992). The Hidden Life. trans. Waltraut Stein. Washington D.C.: ICS Publications.

Stein, Edith, (1993). Self-Portrait in Letters: 1916-1942. trans. Josephine Koeppel. Washington, D.C.: ICS Publications.

Stein, Edith, (2000). Philosophy of Psychology and the Humanities. trans. Mary Catherine Baseheart and Marianne Sawicki. Washington D.C.: ICS Publications.

Stein, Edith, (2002). Finite and Eternal Being. trans. Kurt F. Reinhardt. Washington, D.C.: ICS Publications. 
Stein, Edith, (2009). Potency and Act. trans. Walter Redmond. Washington, D.C: ICS Publications.

Stein, Edith, (2014). Edith Stein: Letters to Roman Ingarden. trans. Hugh C. Hunt. Washington, D.C.: ICS Publications.

Teresa of Avila, (1979). Interior Castle. trans. Kieran Kavanaugh and Otilio Rodriguez. Mahwah, NJ: Paulist Press.

Teresa of Avila, (1997). The Autobiography of St. Teresa of Avila. trans. David Lewis. Rockford, IL: Tan. 